\title{
APPLYING MIXED INTEGER PROGRAMMING FOR GREEN SUPPLY CHAIN MANAGEMENT
}

\author{
A. Sadegheih ${ }^{1^{*}}$, D. Li $^{2}$, S. Sribenjachot ${ }^{3}$ and P.R. Drake ${ }^{4}$ \\ ${ }^{1}$ Department of Industrial Engineering \\ Yazd University, Yazd, Iran \\ sadegheih@yazduni.ac.ir \\ ${ }^{2-4}$ Operations Management and e-Business Group Division \\ University of Liverpool, Management School, Liverpool, UK \\ dong@liverpool.ac.uklll, $\underline{\text { n_nicky2@hotmail.com, Drake@liverpool.ac.uk }}$
}

\begin{abstract}
This paper aims to guide those in supply chain management who make decisions on selecting factories, transportation modes, and the number of products to be manufactured. Solutions can be found through development of an optimisation model, using mixed-integer programming. Because green supply chain issues have become important, and new legislation has to be taken into account, carbon emissions costs must be included in the total costs of the supply chain, as in the optimisation model presented, which then has the ability to minimise total costs and to provide solutions that are both cost-effective and environmentally friendly.
\end{abstract}

\section{OPSOMMING}

Die doel van hierdie artikel is om leiding te verskaf aan diegene in voorsieningskettingbestuur wat besluite neem aangaande die keuse van fabrieke, vervoermetodes en die aantal produkte om te vervaardig. Oplossings kan gevind word by wyse van ' $n$ optimiseringsmodel wat gemengde-heeltalprogrammering gebruik. Aangesien "groen" of te wel omgewingsvriendelike aspekte belangrik geword het en nuwe wetgewing in ag geneem moet word, moet die koste van koolstofemissies in die totale koste van die voorsieningsketting in berekening gebring word, soos wat in die optimiseringsmodel wat voorgehou word inderdaad gebeur. Sodoende kan ' $n$ oplossing gevind word wat nie alleen koste-effektief is nie, maar ook omgewingsvriendelik.

\footnotetext{
${ }^{*}$ Corresponding author
} 


\section{INTRODUCTION}

The problem of network configuration is one of specifying the structure through which products will flow from their source points to demand points. This involves determining: what facilities, if any, are to be used; how many there should be; where they should be located; which products and customers should be assigned to them; which transport services should be used between them; and how the facilities should be served.

It is well known that global warming has become a serious threat, potentially causing disasters such as extreme weather changes, heat waves, severe storms, etc. It is obvious that reducing carbon emissions from transportation would help to reduce it in all sectors. However, emissions from the transportation sector show a tendency to increase continuously. Thus various changes in supply chains will definitely occur in the future, corresponding to new legislation, and transportation will increasingly play a crucial role in reducing carbon emissions [9]. Carbon trading, promoted in terms of the Kyoto Protocol as an environmentally friendly means of pollution control [1], is said to be the best way to help reduce carbon emissions, and will be one focus of this study.

\section{LOGISTICS AND NETWORKS}

Logistics is the function responsible for moving materials through supply chains, where a supply chain is the series of activities and organisations through which materials move on their journey from initial suppliers to final customers. In recent years, organisations have begun to appreciate the importance of logistics, recognising it as an essential function with an obvious impact on strategic performance. Logistics management is essentially an integrative process that seeks to optimise the flows of materials and supplies through the organisation and its operations to the customer. Logistics has always been central to, and essential for, economic activity. Decisions about transportation involve mode selection, shipment size, and routing and scheduling. These decisions are influenced by the proximity of warehouse to customers and plants, which, in turn, influence warehouse location. Transport decisions also affect inventory levels through the size of shipments; and transportation is a significant component of the costs incurred by most supply chains.

In terms of supply chain management, transportation involves movement of the product at the starting point of the supply chain to customers. Transportation can be said to be very significant in the supply chain, because almost all the products are manufactured and consumed in different locations. Moreover, transportation is also a significant cost factor in the supply chain.

It also plays a crucial role in global supply chains. For example, products can be moved and delivered to customers all over the world, although a company may only have a few manufacturing factories. This can be achieved by global transportation. Developed or industrialised societies are characterised by transportation efficiency [23-25].

Supply chains use a combination of transportation modes: road, rail, air, and water. Intermodal services are available to provide special services that cannot be achieved by single transportation services. The effectiveness of any mode of transport is affected by the carrier's investment in equipment and operating decisions, as well as available infrastructure and transportation policies. Environmentally, road transportation is said to be one of the main surface transport sectors emitting $\mathrm{CO}_{2}$ [27].

Airlines have a high fixed cost in infrastructure and equipment. Labour and fuel costs are largely trip-related, and independent of the number of passengers or amount of cargo carried on a flight. An airline's goal is to maximise the daily flying time of a plane and the revenue generated per trip. Because a high level of services and global shipments are increasingly needed, air transport is playing an increasingly important role in distribution in certain parts of the supply chain. 
Water transport is ideally suited for carrying very large loads at low cost, and is used for these reasons. Water transport has different levels of movement limitation, which depend on the availability of waterways [24].

Key issues in the intermodal industry involve the exchange of information to facilitate shipment transfers between different modes, because these transfers often involve considerable delays, reducing delivery time performance. Managers must use information technology to decrease costs and improve responsiveness in their transportation networks (see Tables 1 and 2). Software helps managers with transportation planning, modal selection, and building delivery routes and schedules. Available technology allows carriers to identify the precise location of each vehicle, as well as the shipments it carries. These technologies help carriers to lower costs and become more responsive to changes.

The main benefits of emissions trading in the transport sector are: a reduced impact on climate change; reduced local air pollution; reduced congestion; an increased trend towards localisation; improved health and fitness; enhanced community spirit; increased use of public transport; and an increased uptake of clean fuels and vehicles [28].

\begin{tabular}{|c|c|c|c|c|}
\hline $\begin{array}{c}\text { Economic } \\
\text { characteristics } \\
\text { of network } \\
\text { modes }\end{array}$ & Road & Rail & Air & Water \\
\hline $\begin{array}{c}\text { Fixed costs } \\
\text { Variable costs }\end{array}$ & $\begin{array}{c}\text { Low } \\
\text { Moderate }\end{array}$ & $\begin{array}{c}\text { High } \\
\text { Low }\end{array}$ & $\begin{array}{c}\text { Low } \\
\text { High }\end{array}$ & $\begin{array}{c}\text { Moderate } \\
\text { Low }\end{array}$ \\
\hline Market coverage & $\begin{array}{c}\text { Point to } \\
\text { point }\end{array}$ & $\begin{array}{c}\text { Terminal to } \\
\text { terminal }\end{array}$ & $\begin{array}{c}\text { Terminal to } \\
\text { terminal }\end{array}$ & $\begin{array}{c}\text { Terminal to } \\
\text { terminal }\end{array}$ \\
\hline $\begin{array}{c}\text { Degree of } \\
\text { competition }\end{array}$ & Many & Few & Moderate & Few \\
\hline $\begin{array}{c}\text { Predominant type } \\
\text { of traffic }\end{array}$ & All types & $\begin{array}{c}\text { Moderately } \\
\text { low value, } \\
\text { moderately } \\
\text { high density }\end{array}$ & $\begin{array}{c}\text { High value, } \\
\text { moderately } \\
\text { low density }\end{array}$ & $\begin{array}{c}\text { Low value, } \\
\text { high density }\end{array}$ \\
\hline $\begin{array}{c}\text { Average length of } \\
\text { haul (in } \\
\text { kilometres) }\end{array}$ & 350 & 1600 & 330 & 376 to 1,367 \\
\hline $\begin{array}{c}\text { Equipment } \\
\text { capacity (tonnes) }\end{array}$ & 10 to 25 & 150 to 1,200 & 5 to 125 & 1,000 to 60,000 \\
\hline
\end{tabular}

Table 1: Comparison of network modes (economic characteristics)

\begin{tabular}{|c|c|c|c|c|}
\hline $\begin{array}{c}\text { Service character- } \\
\text { istics of network } \\
\text { modes }\end{array}$ & Road & Rail & Air & Water \\
\hline $\begin{array}{c}\text { Speed } \\
\text { (time-in-transit) }\end{array}$ & $\begin{array}{c}\text { Moderate to } \\
\text { fast }\end{array}$ & Moderate & Fast & Slow \\
\hline Availability & High & Moderate & Moderate & Low \\
\hline Reliability & high & Moderate & High & Low to moderate \\
\hline Loss and damage & Low & Moderate & Low & Low to moderate \\
\hline Flexibility & High & Moderate & Moderate to high & Low to moderate \\
\hline
\end{tabular}

Table 2: Comparison of network modes (service characteristics) 


\section{SUPPLY CHAIN MANAGEMENT}

This review of the literature divides transportation in the supply chain into four major modes - road, rail, air, and water transportation - and explains the performance and difference between transportation modes. Furthermore, this review surveys a range of research related to the use of MIP in supply chain management. Therefore a design network and mode of transportation optimisation model must be created, taking carbon emissions trading into consideration. Its direct benefit is that it lowers the total costs, and its indirect benefit is that it addresses environmental issues, especially problems of global warming.

The optimisation model is developed by using mixed-integer programming. Its structure can be divided into two parts: the objective function, and constraints. The objective function, equation (1), refers to the purpose of the model, which focuses on minimising total costs made up by production costs, fixed costs from factories, fixed and variable transportation costs, carbon emission costs, and opportunity costs. The constraints comprise demands, capacity, and material flows. The designed objective function (1) and constraints (2-7) can be written as the equations shown below:

Objective function:

$$
\begin{aligned}
& \text { MinC }=\sum_{p=1}^{D} \sum_{i=1}^{m} \sum_{j=1}^{n} P C_{i} X_{i j p}+\sum_{i=1}^{m} F F_{i} Y_{i}+\sum_{i=1}^{m} \sum_{p=1}^{D} \sum_{j=1}^{n} F C_{i j p} Y_{j p}+\sum_{p=1}^{D} \sum_{i=1}^{m} \sum_{j=1}^{n} O P_{i j p} X_{i j p} \\
& +\sum_{p=1}^{D} \sum_{i=1}^{m} \sum_{j=1}^{n}\left(T C_{i j p}+C C_{i j p}\right) X_{i j p}
\end{aligned}
$$

In order to give a description of each component in the objective function, the production costs component refers to the price per unit of products ordered from factories. Fixed transportation costs involve expenses (e.g. handling costs) that are never changed, no matter how many products are delivered from factories; whereas variable transportation costs are product volume-varying costs (e.g. rising fuel costs). Opportunity costs mean the calculated expenditure when the other best choices have passed through the decisionmaking process. For example, rail transportation is selected for its low costs, but it is slower than lorries. This forces companies to keep their stocks a little longer while they wait for product delivery. The last component of the objective function is carbon emissions costs, which are incurred by purchasing carbon emissions credits.

As for the constraints, equation (2) simply indicates that all the products delivered from the factories must be equal to the demand.

$$
\sum_{j=1}^{n} \sum_{i=1}^{m} X_{i j p}=D_{p} \quad p=1, \ldots, D
$$

Equation (3) means that none of the factories can supply more than their capacity.

$$
\sum_{p=1}^{D} \sum_{j=1}^{n} X_{i j p} \leq Z_{i} Y_{i} \quad i=1, \ldots, m
$$

Equation (4) involves each mode of transportation not being able to exceed its capacity.

$$
\begin{array}{r}
\sum_{i=1}^{m} X_{i j p} \leq K_{j p} Y_{j p} \quad j=1, \ldots, n \\
p=1, \ldots, D
\end{array}
$$

For equation (5), the number of products shipped must be in a positive range. 


$$
\begin{array}{r}
X_{i j p} \geq 0 \quad i=1, \ldots, m \\
j=1, \ldots, n \\
p=1, \ldots, D
\end{array}
$$

Equations (6) and (7) specify that each transportation mode and factory respectively is either open or closed. These two constraints are used as a binary variable.

$$
\begin{aligned}
& Y_{j p} \in\{0,1\} \quad j=1, \ldots, n \\
& p=1, \ldots, D \\
& Y_{i} \in\{0,1\} \quad i=1, \ldots, m
\end{aligned}
$$

\section{RESULTS FROM MODEL}

The problem is resolved by using the Solver Parameter in Microsoft ${ }^{\circledR}$ Excel ${ }^{\circledR}$. The first step of the calculation is to assume values for all the parameters to be calculated in the objective function and constraints. Figure 1 shows the flow chart of the transportation problem.

The results indicate that the best way to deliver 30,000 units of products to factory $A$ is (1) delivering 19,000 units of products from factory A using road and rail transport, and (2) delivering 11,000 units of products from factory B using port and rail transport. The minimised total costs and the carbon emission, opportunity, variable, fixed transportation, and production costs are $€ 84,540, € 9,070, € 14,540, € 9,180, € 1,050$, and $€ 50,700$ respectively (see Table 3 ).

The carbon emission costs are shown to be $11 \%$, opportunity costs $17 \%$, variable transportation $11 \%$, fixed transportation $1 \%$, and production costs $60 \%$ of the total costs respectively. The traditional approach refers to a general procedure to select transportation modes and factories to deliver products, in this case to a wholesaler. The wholesaler ordered 30,000 product units from three factories $(\mathrm{A}, \mathrm{B}$, and $\mathrm{C})$. Lorries were used to deliver 10,000 units from factory A. Factory $B$ was also ordered to deliver 10,000 units to the wholesaler, but used rail transportation. The other 10,000 units were delivered from factory $\mathrm{C}$ by waterways and rail. The results of the traditional procedure show total costs of $€ 82,990$ : production cost $€ 52,000$, fixed transportation cost $€ 1490$, variable transportation cost $€ 12,100$, and opportunity cost $€ 17,400$. No carbon emissions costs were incurred because carbon emissions were not considered in this case (see Table 4). However, the new legislation regulating carbon emissions has to be included in the transportation sector. From the literature review, it can be seen that many carbon emissions schemes have been proposed. This paper assumes the carbon emissions costs come from purchasing carbon permits from other companies that have extra credits. Thus, carbon emissions costs become part of the total cost, and increase it. The calculations in this case refer to the traditional procedure that takes a new factor - carbon emissions costs - into consideration. It can be seen that the total costs increase to $€ 98,090$ owing to the new legislation aimed at reducing the carbon emitted into the atmosphere. Of this total, carbon emissions costs are $€ 15,100$, or roughly $15 \%$ of the total cost (see Table 5).

Owing to the increase in total cost, companies must find a new approach to making decisions about carbon emissions costs. This new approach is the optimisation model, which leads to changes in the decision-making process: 19,000 units go from factory $A$ by lorry and railroad, 11,000 units go from factory $B$ by waterways and railroads, leading to a decrease in total cost from $€ 98,090$ to $€ 84,540$ - a saving of $€ 13,550$. It is evident that the optimisation model can help to reduce total transportation costs by $13.8 \%$.

In order to study the tendency to make decisions in the light of changes in carbon emissions costs, reductions and increases to the carbon emissions costs by $\pm 5 \%, \pm 10 \%, \pm 20 \%$, and $\pm 30 \%$ 
respectively are applied to the optimisation model (see Table 6). The major reason is that unstable carbon prices are predicted; so studying this expected situation by expanding the range of carbon emissions costs helps us to understand the impact on the decision-making process in supply chains.

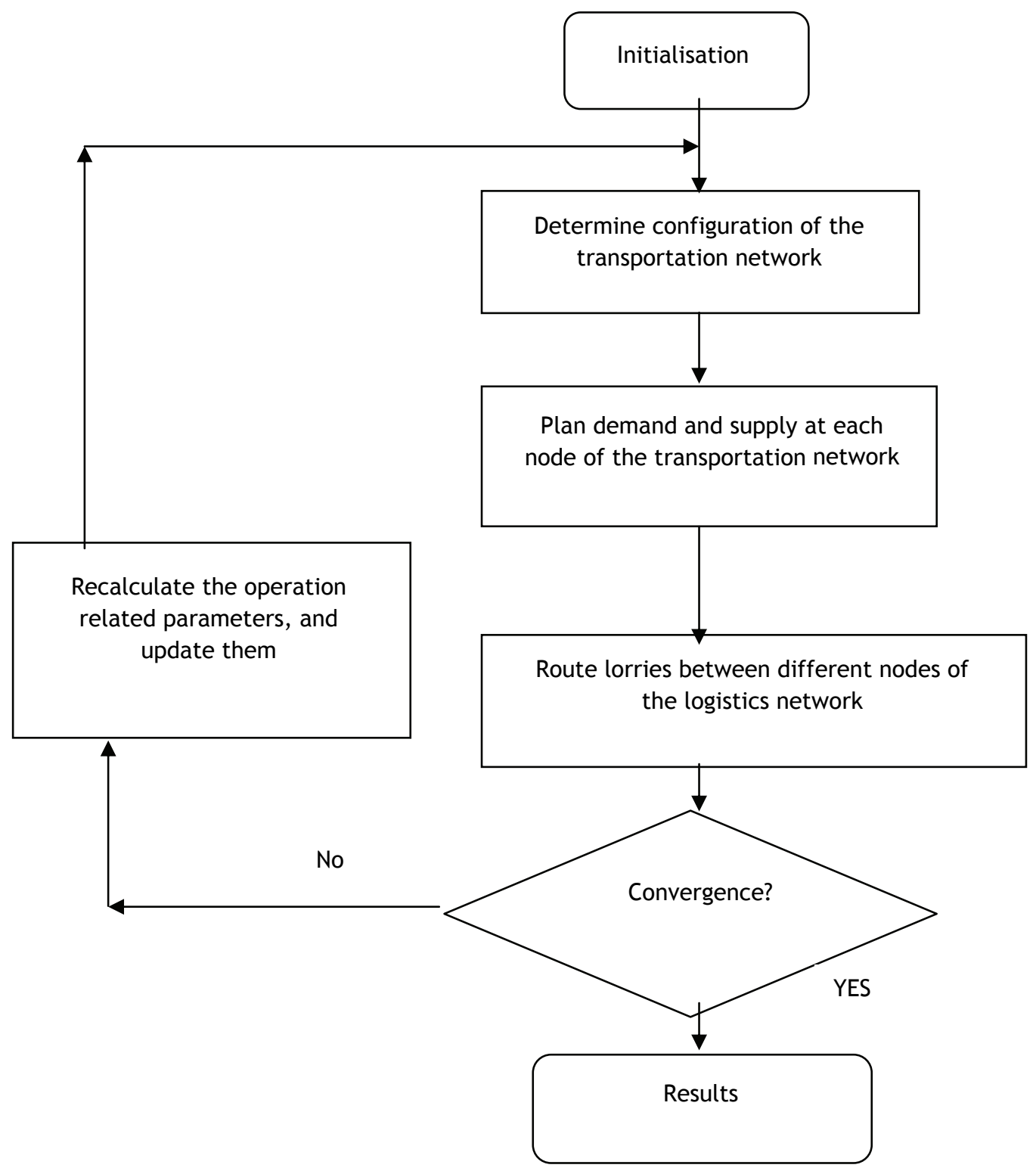

Figure 1: Flow chart of the transportation problem

Despite the changing costs of carbon emissions, the decision to select the factories, the number of products, and transportation modes stays the same as in the optimisation model. It can be seen that changes to the total costs correspond only to the increase and decrease in carbon emissions costs. However, it is necessary to obtain further results, in case the carbon emissions costs increase dramatically. 
The penalty charge of $€ 40$ per tonne of carbon was indicated in the first phase of the EUETS (European Union Emission Trading Scheme), and $€ 100$ per tonne of carbon in the second phase. The current carbon prices are $€ 22$ to $€ 25$ per tonne of carbon. The penalty charge for carbon emissions is $100 \%$ higher than the market prices for phase I, and about $300 \%$ higher for phase II. So this research will increase the carbon emissions costs by $100 \%$ and $300 \%$ in order to see whether or not the decisions will be impacted. The transportation modes and factories selected are the same as those in the optimisation model when the carbon emissions costs increase by $100 \%$. However, the number of products is reduced from 19,000 to 12,000 units for factory $A$, and increased from 11,000 to 18,000 for factory $B$. Moreover, after the carbon emissions costs increase by $300 \%$, both the transportation modes and the factories selected to deliver products are changed.

The intermodal transportation of waterways and railroads is selected to deliver 12,000 units of products from factory C, and 18,000 units of products from factory B. Now it can be seen that the decision is changed when the carbon emissions costs increase by $100 \%$ or more. Thus it can be concluded that decisions can be dramatically affected by changing only one factor, in this case the carbon emissions costs (see Tables 7 and 8). This situation may arise in the future; the demand for carbon permits may be higher than the supply because only a few carbon permits may be traded in the markets. In this case many firms will incur the penalty charge owing to the shortage of carbon permits. In terms of environmental impact on logistics and supply chain management, when carbon emissions trading is implemented, the costs of industrial development will increase because of the investment in new types of green technology to reduce carbon emissions. Furthermore, implementing the carbon emissions trading schemes results in new business strategies, because environmental issues are included in decision-making processes by considering the environmental impact of proposed actions and alternatives to those actions. The energy costs, taxes, legislation, demands, etc. are all factors that contribute to carbon emissions strategies and decisionmaking processes.

The approach to reducing carbon emissions can require companies to adapt themselves strategically to environmental issues. Carbon emissions reduction strategies can be beneficial because they encourage companies to analyse the solutions to green issues. Integrating environmental issues into decisions made in all parts of supply chains opens the way to sustainable development. This principle has been widely adopted in many countries, and firms have launched a voluntary integration of environmental concerns into the operational levels of supply chain management. Environmental Impact Assessments (EIA) have been increasingly integrated into organisational policies to analyse and identify possibly significant impacts of logistics and supply chains on the global environment [2931].

In supply chain management, there are further factors such as procedures to measure and calculate transportation emissions. There are many factors that contribute to decreasing demands for transportation, most of which are related to rising fuel costs. This means that configurations of production and distribution can reduce the demand for freight transport. Relocating facilities leads to carbon reduction. Reducing carbon emissions from the transportation sector can be achieved by increasing the energy efficiency of transport operations. In the transportation sector, engine efficiency, motorways, driving behaviours, speeds, tyre pressures, and wind speed and direction are all important factors that contribute to energy consumption. However, these factors are affected by increasing fuel prices. Operations of freight transports have been developed over many years to reduce costs. Nowadays, environmental issues have become part of operational decision-making processes, which can be seen in the integration of energy efficiency policy in organisations. This allows companies to improve their operational transport processes. Moreover, fully or partially changing modes of transportation can also reduce carbon emissions. 


\begin{tabular}{|l|l|l|}
\hline Factory & Quantity & \multicolumn{2}{|l|}{ Mode of network } \\
\hline A & 19,000 & Road+Rail \\
\hline B & 11,000 & Port+Rail \\
\hline C & - & - \\
\hline Costs & EUR \\
\hline Production cost & 50,700 \\
\hline Fixed cost & 1,050 \\
\hline Variable cost & 9,180 \\
\hline Carbon emission cost & 9,070 \\
\hline Opportunity cost & 14,540 \\
\hline Total cost & 84,540 \\
\hline
\end{tabular}

Table 3: Decisions and results of the mixed integer programming

\begin{tabular}{|l|l|l|}
\hline Factory & Quantity & Mode of network \\
\hline A & 10,000 & Road \\
\hline B & 10,000 & Rail \\
\hline C & 10,000 & Port+Rail \\
\hline Costs & & EUR \\
\hline Production cost & & 1,490 \\
\hline Fixed cost & & 12,100 \\
\hline Variable cost & & 17,400 \\
\hline Opportunity cost & & 82,990 \\
\hline Total cost &
\end{tabular}

Table 4: Decisions and results of traditional approach

\begin{tabular}{|l|l|l|}
\hline Factory & Quantity & Mode of network \\
\hline A & 10,000 & Road \\
\hline B & 10,000 & Rail \\
\hline C & 10,000 & Port+Rail \\
\hline Costs & \multicolumn{2}{|c|}{ EUR } \\
\hline Production cost & & 1,490 \\
\hline Fixed cost & & 12,100 \\
\hline Variable cost & & 15,100 \\
\hline Carbon emission cost & & 17,400 \\
\hline Opportunity cost & & 98,090 \\
\hline Total cost &
\end{tabular}

Table 5: Results of traditional procedure including carbon emissions costs

\begin{tabular}{|l|r|r|r|r|r|r|r|r|r|}
\hline Costs & $-30 \%$ & $-20 \%$ & $-10 \%$ & $-5 \%$ & MIP & $5 \%$ & $10 \%$ & $20 \%$ & $30 \%$ \\
\hline $\begin{array}{l}\text { Production } \\
\text { costs }\end{array}$ & 50,700 & 50,700 & 50,700 & 50,700 & 50,700 & 50,700 & 50,700 & 50,700 & 50,700 \\
\hline $\begin{array}{l}\text { Fixed } \\
\text { costs }\end{array}$ & 1,050 & 1,050 & 1,050 & 1,050 & 1,050 & 1,050 & 1,050 & 1,050 & 1,050 \\
\hline $\begin{array}{l}\text { Variable } \\
\text { costs }\end{array}$ & 9,180 & 9,180 & 9,180 & 9,180 & 9,180 & 9,180 & 9,180 & 9,180 & 9,180 \\
\hline $\begin{array}{l}\text { Carbon } \\
\text { emission } \\
\text { costs }\end{array}$ & 6,349 & 7,256 & 8,163 & 8,617 & 9,070 & 9,524 & 9,977 & 10,884 & 11,791 \\
\hline $\begin{array}{l}\text { Opportunity } \\
\text { costs }\end{array}$ & 14,540 & 14,540 & 14,540 & 14,540 & 14,540 & 14,540 & 14,540 & 14,540 & 14,540 \\
\hline Total Costs & 81,819 & 82,726 & 83,633 & 84,087 & 84,540 & 84,994 & 85,447 & 86,354 & 87,261 \\
\hline
\end{tabular}

Table 6: Calculated results after changing carbon emissions costs 


\begin{tabular}{|c|c|c|c|}
\hline $\begin{array}{c}\text { Factory A } \\
\text { transport mode }\end{array}$ & MIP & $100 \%$ & $300 \%$ \\
\hline Road & - & - & - \\
\hline Rail & - & - & - \\
\hline Road + Rail & 19,000 & 12,000 & - \\
\hline Port + Road & - & - & - \\
\hline Port + Rail & - & - & - \\
\hline $\begin{array}{c}\text { Factory B } \\
\text { transport mode }\end{array}$ & MIP & $100 \%$ & $300 \%$ \\
\hline Road & - & - & - \\
\hline Rail & - & - & - \\
\hline Road + Rail & - & - & - \\
\hline Port + Road & - & - & - \\
\hline Port + Rail & 11,000 & 18,000 & 18,000 \\
\hline $\begin{array}{c}\text { Factory C } \\
\text { transport mode }\end{array}$ & MIP & $100 \%$ & $300 \%$ \\
\hline Road & - & - & - \\
\hline Rail & - & - & - \\
\hline Road + Rail & - & - & - \\
\hline Port + Road & - & - & 12,000 \\
\hline Port + Rail & - & - & \\
\hline
\end{tabular}

Table 7: Selections of transportation modes and factories in cases of penalty charge

\begin{tabular}{|l|r|r|r|}
\hline \multicolumn{1}{|c|}{ Costs } & \multicolumn{1}{c|}{ MIP } & \multicolumn{1}{c|}{$100 \%$} & \multicolumn{1}{c|}{$\mathbf{3 0 0 \%}$} \\
\hline Production cost & 52,000 & 48,600 & 49,800 \\
\hline Fixed cost & 1,050 & 1,050 & 700 \\
\hline Variable cost & 9,180 & 8,340 & 7,170 \\
\hline Carbon emission cost & 9,070 & 16,320 & 24,960 \\
\hline Opportunity cost & 14,540 & 19,020 & 25,260 \\
\hline Total cost & 84,540 & 93,330 & 107,860 \\
\hline
\end{tabular}

Table 8: Calculated results in cases of the penalty charge

\section{CONCLUSIONS}

This paper has highlighted the vast potential for tradable permit schemes in order to achieve significant and vital reductions in greenhouse gas emissions. In addition, the alternative approaches investigated appear unlikely to deliver similar or better results than an emissions trading scheme.

Several approaches to emissions trading were investigated. Various strengths and weaknesses were identified among the various options. Inevitably in an emissions trading scheme, there are trade-offs between the key issues of acceptability, equity, efficiency, and cost. These issues become more or less apparent depending on the system design, in terms of scope, permit allocation, and monitoring processes and efficiency.

The various carbon emission control methods are tax models; trading schemes; fuel systems; traffic control systems; political acceptability control costs; global climate change policy; improving vehicle maintenance standards; reduced emissions standards; global and local emissions; lowering demands for transport; global sourcing; supply chain and logistics network design; environment integration into decision-making processes; and improvement 
of energy efficiency. In this case, new green developments need to be included in the supply chain management. The design optimisation model falls into this approach because it includes carbon emissions costs, allowing companies to obtain cost-effective and environmentally friendly solutions. This demonstrates why the transportation design model under the carbon emissions trading programme, using mixed-integer programming, has been developed in this paper. The value of this research is that it allows companies to make the best decisions in selecting the modes of transport, the number of products, and which factories to use. The solutions are achieved by minimising the total costs, including carbon emissions costs; and those decisions are cost-effective and environmentally friendly.

As a result of this study, when carbon emissions costs are considered among the financial burdens, the decisions of the optimisation model produce lower total costs compared with the traditional procedure. Furthermore, in the event that carbon emissions costs are expanded beyond a small range, making carbon emissions market prices unstable, the decisions are not affected. But the decisions will necessarily change if companies face penalty charges, which represent a dramatic increase in carbon emissions costs. It can therefore be concluded that carbon emissions costs affect the decision-making process.

\section{NOTATIONS:}

$i$ :Factories index

$j:$ Transportation modes index

$n:$ Number of transportation modes

$m:$ Number of factories

$p:$ Wholesaler index

$D$ : Number of wholesaler

$X_{i j p}$ : Quantity shipped from factory $i$ to wholesaler $p$ by using mode $j$

$Y_{j p}: 1$ if transportation mode $j$ to wholesaler $p$ is open, 0 otherwise

$Y_{i}: 1$ if factory $i$ is open, 0 otherwise

$P C_{i}$ : Unit production cost from factory $i$

$F C_{i j p}$ : Fix transportation cost from factory $i$ to wholesaler $p$ by using mode $j$

$T C_{i j p}$ : Unit variable transportation cost from factory $i$ to wholesaler $p$ by using transportation mode $j$

$C C_{i j p}$ : Unit carbon emission cost from factory $i$ to wholesaler $p$ by using transportation mode $j$

$O P_{i j p}$ : Unit opportunity cost from factory $i$ to wholesaler $p$ by using transportation mode $j$

$D_{p}:$ Demand at wholesaler $p$

$K_{j p}$ : Potential capacity of transportation mode $j$ to wholesaler $p$

$Z_{i}$ : Potential capacity of factory $i$

$F F_{i}$ : Fixed cost from factory $i$

\section{ACKNOWLEDGEMENTS}

This research was supported by the Universities of Yazd (Iran) and Liverpool (UK). 


\section{REFERENCES}

[1] Decanio, S.J. 1992. International cooperation to avert global warming: Economic growth, carbon pricing, and energy efficiency, The Journal of Environment and Development, 1, pp 41-62.

[2] Metcalf, G.E. 2007. Corporate tax reform paying the bills with a carbon tax, Public Finance Review, 35, pp 440-459.

[3] Lutter, R. \& Shogren, J.F. 2002. Tradable permit tariffs: How local air pollution affects carbon emissions permit trading, Land Economics, 78, pp 159-170.

[4] Babiker, M.H., Criqui, P., Ellerman, A.D., Reilly, J.M. \& Viguier, L.L. 2003. Assessing the impact of carbon tax differentiation in the European Union, Environmental Modelling and Assessment, 8, pp 187-197.

[5] Herber, B.P. \& Raga, J.T. 1995. An international carbon tax to combat global warming: An economic and political analysis of the European Union proposal, The American Journal of Economics and Sociology, 54, pp 257-267.

[6] Spru, S.S. 2003. Carbon trading in the policy mix, Oxford Review of Economic Policy, 19, pp 420-437.

[7] Monni, S., Syri, S., Pipatti, R. \& Savolainen, I. 2007. Extension of EU emissions trading scheme to other sectors and gases: Consequences for uncertainty of total tradable amount, Water Air and Soil Pollution: Focus, 7, pp 529-538.

[8] Reilly, J., Mayer, M. \& Harnisch, J. 2002. The Kyoto Protocol and non- $\mathrm{CO}_{2}$ greenhouse gases and carbon sinks, Environmental Modelling and Assessment, 7, pp 217-229.

[9] Dumanski, J. 2004. Carbon sequestration, soil conservation, and the Kyoto Protocol: Summary of implications, Climatic Change, 65, pp 255-261.

[10] Clémençon, R. 2008. The Bali road map: A first step on the difficult journey to a Post-Kyoto Protocol agreement, The Journal of Environment Development, 17, pp 70-94.

[11] Bohringer, C. 2003. The Kyoto Protocol: A review and perspectives, Oxford Review of Economic Policy, 19, pp 451-466.

[12] Parry, I.W.H. 2003. Fiscal interactions and the case for carbon taxes over grandfathered carbon permits, Oxford Review of Economic Policy, 19, pp 385-399.

[13] Helm, D., Hepburn, C. \& Mash, R. 2003. Credible carbon policy, Oxford Review of Economic Policy, 19, pp 438-450.

[14] Callan, T., Lyons, S., Scott, S., Tol, R.S.J. and Verde, S. 2009. The distributional implications of a carbon tax in Ireland, Energy Policy, 37, pp 407-412.

[15] Keppens, M. \& Vereeck, L. 2003. The design and effects of a tradable fuel permit system, Association for European Transport, presented at the European Transport Conference.

[16] Watters, H. \& Tight, M. 2007. Designing an emissions trading scheme suitable for surface transport, Institute for Transport Studies, Faculty of Environment, University of Leeds.

[17] Kengpol, A. 2008. Design of a decision support system to evaluate logistics distribution network in Greater Mekong Sub-region countries, International Journal of Production Economics, 115, pp 388-399.

[18] Ma, H. \& Suo, C. 2006. A model for designing multiple products logistics networks, International Journal of Physical Distribution \& Logistics Management, 36, pp 127135.

[19] Chopra, S. \& Meindl, P. 2007. Supply chain management strategy: Planning and operations. $3^{\text {rd }}$ ed., Pearson Education, Inc., New Jersey.

[20] Canel, C. \& Khumawala, B.M. 1996. A mixed-integer programming approach for the international facilities location problem, International Journal of Operations \& Production Management, 16, pp 49-68.

[21] Ostermark, R. 2007. A flexible platform for mixed-integer non-linear programming problems, Kybernetes, 36, pp 652-670.

[22] UNEP and UNCTAD. 2003. An emerging market for the environment: A guide to emissions trading, UNEP Collaborating Centre on Energy and Environment (UCCEE). 
[23] Dobes, L. 1998. Tradable permits in transport, Conference on 'Kyoto - the Impact on Australia', Australian APEC Study Centre, Melbourne.

[24] Watters, H. 2005. Tradable carbon permits: Reducing $\mathrm{CO}_{2}$ from the transport sector, Presentation at European Transport Conference, Strasbourg.

[25] Starkey, R. \& Anderson, K. 2005. Domestic tradable quotas: A policy instrument for reducing greenhouse gas emissions from energy use, Tyndall Technical Report 39, Tyndall Centre for Climate Change Research.

[26] Waters, D. 2007. Global logistics: News directions in supply chain management, $5^{\text {th }}$ ed., Kogan Page Limited, London.

[27] Wadud, Z., Noland, R.B. \& Graham, D.J. 2008. Analysis of personal tradable carbon permits for the road transport sector, Environmental Science \& Policy, 11, pp 533544.

[28] Raux, C. 2004. The use of transferable permits in transport policy, Transportation Research Part D, 9, pp 185-197.

[29] Angell, L.C. and Klassen, R.D. 1999. Integrating environmental issues into the mainstream: An agenda for research in operations management, Journal of Operations Management, 17, pp 575-598.

[30] Robert, L. \& Bradley, R.L. 2003. Climate alarmism reconsidered, Institute of Economic Affairs, London.

[31] Sadegheih, A. 2010. A novel formulation of carbon emissions costs for optimal design configuration of system transmission planning, Renewable Energy, 35, pp. 1091-1097. 